ЖУРНАЛИСТИКА

DOI: $10.17805 /$ trudy.2016.3.1

\title{
ОБРАЗОВАНИЕ КАК СТРАТЕГИЧЕСКИЙ РЕСУРС
}

\author{
Ю. А. Головин \\ (Московский гуманитарный университет)
}

\begin{abstract}
Аннотация: В статье автор анализирует современную систему образования и отмечает, что на сегодняшнем этапе развития цивилизации глобальное, повсеместное, насильственное внедрение либеральных ценностей и либеральной идеологии отменило, в конечном итоге, общечеловеческие цеенности, мораль, нравственность. Либеральному, рыночному обществу не нужны личности, а, следовательно, вообще не нужно фундаментальное гуманитарное образование, воспитывающее эти личности - нужны послушные исполнители и активные потребители.
\end{abstract}

Ключевые слова: российское образование; либеральные ценности; идеология; воспитание; советская система образования; Болонский процесс; коммерциализация системы образования

\section{EDUCATION AS A STRATEGIC RESOURCE}

\author{
Yu. A. Golovin \\ (Moscow University for the Humanities)
}

\begin{abstract}
The author analyzes the contemporary system of education and notes that at the current stage of the development of the global civilization, widespread, forcible introduction of liberal values and liberal ideology has eventually canceled out universal values, morality and ethics. Liberal society based on free market does not need individuals and, therefore, does not need fundamental education in the humanities. Its pillars are, rather, obedient agents and active consumers.
\end{abstract}

Keywords: education in Russia; liberal values; ideology; upbringing; Soviet system of education; Bologna process; commercialization of educational system

Закон маятника никто не отменял. Дойдя до предела влево, он, если, конечно, на него не будет прямого воздействия каких-нибудь внешних сил, обязательно практически на то же расстояние отклонится вправо. В середине 90-х годов XX века наше образование, впрочем, как и большинство процессов в стране, дошло до своей крайней точки в движении к капитализму. И не просто к капитализму, а к его суперлиберальной мо- 
дели, каковой, кстати сказать, в так называемом цивилизованном мире, куда мы активно стремились, по сути, уже давно не было. К сожалению, во главу угла была поставлена одна, главенствующая на тот момент идея: советская система образования, как якобы не отвечающая современным вызовам, должна быть полностью разрушена. И ее успешно разрушили.

Сегодня, критикуя, и вполне справедливо, десоветизацию на Украине, мы стыдливо забываем, что точно такой же, а может и еще яростнее, процесс происходил в середине 1990-х в России. Многие герои тех дней и сегодня живы-здоровы и даже благоденствуют. Чубайс, Фурсенко, Авен, Мамут и т. д. Впрочем, не в героях дело, а в сути. В частности, из школы знаний, умений и навыков, лежавших в основе советского образования, вся система переориентировалась ныне на школу компетенций, практикуемую в США.

Параллельно, вместе с идеологией, из российской системы образования, как школьного, так и вузовского, было полностью исключено понятие «воспитание» (Ильинский, 2016). Дескать, воспитает сама система, в данном случае, рыночная. А относительно конкретных людей, реальных образовательных учреждений был вброшен простой и понятный лозунг «Обогащайтесь!» А чтобы этот беспрецедентный процесс разрушения собственного образования, уничтожения своего менталитета, а значит, и своего будущего выглядел хоть как-то научно обоснованным, была поставлена изначально невыполнимая, но по-популистски привлекательная задача: внедриться в мировую систему образования. В данном случае, в так называемый Болонский процесс. И даже сегодня, когда стало очевидным, что ни в какую мировую систему образования мы так и «не вошли», что ни в одной стране мира, ни в одной системе образования, будь то «немецкая», «английская», «американская» или «китайская», такого понятия как «болонский процесс» нет и в помине, наши либеральные политики его именем продолжают разваливать российскую высшую школу. Беда, видимо, в том, что чиновники от образования так и не решили до сих пор, а может, до сих пор не получили четкой команды, о том, что же они хотят иметь вместо разрушенной советской системы. Никакой «болонской», за которой они почти два десятка лет прикрывали свои реформы и успешное отмывание денег, понятно, нет, но нет и никакой российской. Не просматривается даже вектор, по которому бы шло развитие. Нельзя же всерьез назвать реформой судорожный процесс штамповки бесконечно новых правил и положений. Чем, к примеру, отличается ФГОС 3 от ФГОС 3+? Coкращением количества компетенций. Всё! Некоторые «новые» ФГОСы не просуществовали и года.

Что это означает для учебно-методических управлений вузов, для деканатов, кафедр и педагогов, для всего учебного процесса (Ковалева, 2015: 18)? Десятки, сотни и тысячи часов бессмысленной бесполезной ра- 
боты по переработке и утверждению новых основных образовательных программ (ООП), образовательных программ (ОП), рабочих программ, учебных планов, по сути ничего не меняющих в самой системе образования, а главное, в ее содержании.

Понятна, к примеру, цель, поставленная министром образования, о сокращении нескольких сот вузов, не отвечающих образовательным стандартам. Действительно, в тот самый суперлиберальный период, когда маятник отклонился максимально вправо, под лозунг «обогащайтесь», большинство вузов, чтобы попросту выжить, открывали наиболее «рыночные» направления - схема была достаточно упрощена, создавали иучебные заведения, попросту торгующие дипломами, и их филиалы, лишь собирающие деньги у населения.

Но когда за дело взялись чиновники, вдруг выяснилось, что «правила», по которым происходит сокращение, расплывчаты, что они никак не определяют самого главного - «качества образования». Вузы, а затем и школы закрывались по чисто формальному признаку. С 2001го по 2013 г. в России закрылось 24000 школ и 320 вузов (данных после 2013г. на сайте Росстата нет, видимо информацию решили «засекретить») (Александрова-Зорина, 2016: 3). Более того, они в любой момент волей чиновника могут поменяться, а то и вовсе подменяться. «Под нож» пошли и вполне респектабельные вузы, а тысячи профессиональных педагогов остались без работы. Иногда кому-то нужны были здания, иногда объединение происходило под «нужного человечка», да мало ли интересов у тех, кто служение России, как то положено по должности, расценивает как собственный бизнес.

Понятны и мотивы майских указов Президента о повышении заработной платы педагогам и ревностный контроль за их исполнением со стороны министерства образования. Но и здесь получилось по Черномырдину: «Хотели как лучше, а получилось как всегда». Зарплаты одних взлетели до небес, у других же буквально вросли в землю. Да, средняя зарплата педагога выросла. Министерства и ведомства тут же отчитались перед Президентом. Но даже в самых престижных вузах, где зарплаты руководителей составляют десятки и даже сотни миллионов рублей в год зарплаты профессорско-преподавательского состава даже сократились. Очевидно также, что маятник со свистом летит в обратную сторону. И на смену вседозволенности и лозунгу «берите независимости, сколько осилите» приходит всеохватная «вертикаль». Но с каждым годом, особенно в условиях экономического кризиса, «вертикаль» все больше работает на себя.В том числе, и в образовании. Вот небольшая иллюстрация.

Доходы элиты российских ректоров, кстати сказать, главных идеологов либерального направления в экономике, в десятки, а то и сотни раз превышают сегодня средние доходы профессорско-преподавательского 
состава подчиненных им вузов. Вот как, по мнению журнала «Форбс», в 2014 г. выглядела линейка доходов лидеров: первый проректор Высшей школы экономики Леонид Гохберг - 40 млн рублей; ректор Всероссийской Академии внешней торговли Сергей Синельников-Мурылев - 37,8 млн рублей; ректор Российской академии народного хозяйства и государственной службы при Президенте РФ Владимир Мау - 36,9 млн рублей. Можно назвать еще сотни руководителей вузов, чьи доходы превышают миллионы и десятки миллионов рублей. Зарплата же рядового профессора в данных вузах колеблется от 18 до 40 тыс. рублей. То же происходит и в колледжах и школах. Нам с гордостью докладывают ос виду приличной средней зарплате учителей, но для всех очевидно, что это лишь «средняя температура по больнице». Можно привести десятки и сотни примеров, подтверждающих вышесказанное.

Важно другое, образование с одной стороны, в силу закона маятника стало жестко регламентированным, попав под всеохватывающую вертикаль, дающую возможность чиновникам творить там, что угодно или что выгодно. А с другой стороны, оно стало насквозь коммерциализированным. То есть в плане идеологии находится под зорким оком либеральных воззрений и крайне рыночных отношений. И если в вопросах качества образования мы не продвинулись ни на йоту, а по сравнению с «советским» и вовсе откатились далеко назад, то в плане идеологии, мы, безусловно, «победили все «советское»», которое тем не менее опиралось на основополагающие социальные принципы: бесплатное и доступное образование для всех категорий населения страны и более менее справедливое распределение доходов. По сути, мы жестко вогнали себя в колею либеральных представлений, заболев при этом всеми болезнями развитого либерализма, характерного для сегодняшнего «цивилизованного» общества. И первая, главная болезнь, заключается в том, что государство практически снимает с себя все обязательства по поводу российского образования, то есть будущего страны. А современная российская элита, порожденная вороватым российским капитализмом (это уже чисто наша особенность), превратив государственную службу в собственный бизнес, радеет исключительно о собственном благополучии и живет практически в условиях ультралиберального капитализма. По крайней мере, в экономическом плане ее интересы, как ни странно и не печально, полностью совпадают с интересами мировой элиты.А они очень просты: в основе развития цивилизации лежит всемерное, безграничное потребление. А в мире существуетлишь один смысл, один бог, одна иерархия - деньги.

Отсюда понятно, что либеральному, рыночному обществу не нужны личности, а, следовательно, вообще не нужно глубокое, тем более, гуманитарное образование, воспитывающее эти личности - нужны послуш- 
ные исполнители и активные потребители (Коханая, Головин, 2016: 317).

Конечно, этот вопрос легче всего решается еще на уровне образования, которое является лакмусовой бумажкой. Именно по отношению к образованию либералы узнают «своих». В «цивилизованном» мире так же, как и у нас, образование становится все более коммерческим, капитализированным и профилированным. Конечно, надо понимать, что не конкретным чиновникам в сфере образования не нужен конкретный образованный, мыслящий человек с гуманитарным образованием, аналитическим мышлением, с ясными представлениями о совести, морали, человеческом достоинстве. Он не нужен системе потребления. Чем выше образован человек, тем он меньше предрасположен покупать всякую разрекламированную ерунду, тем он губительнее для системы потребления, он почти бессмысленен для рынка, а значит, и для тех, кто эти рынки в конечном итоге контролирует, для всех представляющих сегодня так называемую российскую элиту. В данном случае, они, как очень богатые и влиятельные владельцы и топ-менеджеры, чье личное благополучие напрямую зависит от рынка, как часть системы и одни из ее апологетов, осознано или неосознанно (это не так уж и важно), выполняют роль санитаров на своих конкретных местах. Не секрет ведь, что за каждым серьезным банком, компанией, сетью, производством, даже простого майонеза, по крайней мере, у нас в России, стоит крупный, зачастую очень крупный чиновник. Понятно, что он и является заинтересованным охранником этой системы по производству потребителей.

Очевидно, что все эти современные реформы в образовании: ЕГЭ, болонские процессы, ФГОСы «плюс и минус», разного рода оптимизации и автономизации, и прочая, прочая - на самом деле обыкновенная капитализация образования, а через нее - и это уже идеология - попытка создания идеального потребителя. Это у Пифагора в математической школе, прежде всего, учили музыке и высокой поэзии Гомера и Гесиода. Это у Бога в начале, было Слово. У либералов профессиональный компьютерщик и пронырливый менеджер важнее любого Платона и Достоевского. Идеально, если он вообще забудет и о своей национальности, и вероисповедании, и культуре (Смеюха, 2015: 104; Коханая, 2014: 75). Он, по задумке либеральных идеологов и логике самого процесса, не должен сомневаться, думать, тем более размышлять (Шилина, 2015: 108). Он должен стремиться получать как можно больше денег, а затем приобретать как можно больше «престижного» товара и тем самым перебираться на якобы все более высокую ступень потребительской лестницы тщеславия. Об этом кричат все средства массовой коммуникации в мировом масштабе, для этого работает гигантская рекламная индустрия - она и воспитывает. Может, именно поэтому из всех образовательных программ напрочь 
исчезло понятие «воспитание» (Ильинский, Луков, 2015: Электр. ресурс).

А как же Запад? - возразят профессиональные хитрецы и оболваненные ими потребители. Запад, уважаемые, живет ровно по тем же законам. Вот, к примеру, что пишет об английском образовании, самом престижном, по мнению российских нувориш, профессор Оксфордского университета г-н Терри Иглтон в своей статье «Медленная смерть университета»: «В центре развала английского образования оказались припертые к стене гуманитарии... Жадные до денег, британские университеты позволяют сегодня студентам, никак не проявившим себя в бакалавриате, поступать в магистратуру, а иностранные студенты (платящие втридорога) могут оказаться в докторантуре, не владея английским языком... По мере того как преподаватели становятся менеджерами, студенты превращаются в потребителей... Вузы давят на преподавателей, чтобы те не ставили плохих оценок, ведь это риск потерять деньги... Научные заслуги зависят от того, сколько денег вы способны заработать, в то время как хорошее образование приравнивается к трудоустройству...» (Иглтон, 2015: Электр. ресурс). И там же вывод: «Обучение молодых людей, как и защиту от серийных убийц, следует рассматривать в качестве социальной ответственности, а не как повод для получения прибыли» (там же). Не правда ли, похоже? Просто по российской традиции и в связи со скоропостижным обогащением в «лихие девяностые» определенного круга людей, все у нас еще более явно и открыто.

Отсюда, понятно, и там и здесь самый бесполезный, а значит, опасный для рынка человек - это святой. А самый желанный - должен быть абсолютно развращен и извращен. Его-то, идеального потребителя, и выращивают сегодня либеральные чиновники всех мастей. Под его любые фантазии рынок обязательно подстроится и настроится. А значит, хозяева получат Ее величество прибыль, то есть деньги, а значит, и власть.

Именно образование - стратегический ресурс будущего (Шкондин, Демина, 2015), и именно здесь ведется самая ожесточенная и изощренная война. Ведь победитель получит все. Впрочем, надежда еще есть, тем более что «закон маятника» работает даже в России, и никакие чиновники не в состоянии его отменить.

\section{СПИСОК ЛИТЕРАТУРЫ}

Александрова-Зорина, Е. (2016) Россия в яме стабильности // Московский комсомолец, №130 (27.132), 23 июня. С. 3.

Иглтон, Т. (2015) Медленная смерть университета [Электронный ресурс] // Скепсис. URL: http://scepsis.net/library/id_3672.html (дата обращения: 15.06.2016).

Ильинский, И. М. (2016) Воспитание новых поколений: назревшие 
проблемы // Знание. Понимание. Умение. № 2. C. 5-12. DOI: http://dx.doi. org/10.17805/zpu.2016.2.1

Ильинский, И. М., Луков, В. А. (2015) О стратегии развития воспитания в Российской Федерации на период до 2025 года [Электронный ресурс] // Научные труды Московского гуманитарного университета. № 1 (169). URL: http://journals.mosgu.ru/trudy/article/view/6 (дата обращения: 15.06.2016). DOI: http://dx.doi.org/10.17805/trudy.2015.1.6

Ковалева, А. И. (2015) Новые подходы к реализации основных образовательных программ в вузах // / Сборник материалов ; под общей редакцией вице-президента Ассоциации Коммуникационных Агентств России (AКАР), заведующего кафедрой «Рекламы и связей с общественностью» РАНХиГС Доктора филологических наук, профессора Евстафьева В. А. (руководитель конференции). М. : Издательство Московского гуманитарного университета. 404 с. С. 17-24.

Коханая, О. Е. (2014) Особенности освещения православной тематики в медийной среде // Труды Ростовского государственного университета путей сообщения. № 1 (26). С. 75-79.

Коханая, О. Е., Головин, Ю. А. (2016) Критика либеральной идеологии как концепта в парадигме медиаобразования // Вопросы теории и практики журналистики. Т. 5. № 2. С. 314-323.

Смеюха, В. В. (2015) Возможности развития образовательных процессов: от чтения книг к общению в социальных медиа // Высшее образование для XXI века: XII Международная научная конференция.г. Москва, 3-5 декабря 2015 г. Доклады и материалы. Круглый стол «Современные тенденции медиаобразования» / отв. ред. О. Е. Коханая. М. : Изд-во Московского гуманитарного университета. С. 101-106.

Шилина, А. Г. (2015) Миротворческая миссия (масс)медиалингвистики в контексте информационно-психологической войны // Высшее образование для XXI века: XII Международная научная конференция. г. Москва, 3-5 декабря 2015 г. Доклады и материалы. Круглый стол «Современные тенденции медиаобразования» / отв. ред. О. Е. Коханая. М. : Изд-во Московского гуманитарного университета. С. 106-109.

Шкондин, М. В., Демина, И. Н. (2015) Медиасистема: аспекты синергетического анализа // Вопросы теории и практики журналистики. Т. 4. №4. C. 456-461. DOI: http://dx.doi.org/10.17150/2308-6203.2015.4(4).456-461

Головин Юрий Алексеевич - доктор культурологии, кандидат филологических наук, профессор, заведующий кафедрой журналистики Московского гуманилтарного университета. Адрес: 111395, Россия, г. Москва, ул. Юности, д. 5. Тел.: +7 (499) 374-60-91. Эл. адрес: ygolovin51@gmail.com 
Golovin Yuri Alexeyevich, Doctor of Culturology, Candidate of Philology, Professor and Chair, Department of Journalism, Moscow University for the Humanities. Postal address: 5 Yunosti St., 111395 Moscow, Russian Federation. Tel.: +7 (499) 374- 60-91. E-mail: ygolovin51@gmail.com 